\title{
Technology as an influential variable in the development of dialogical learning
}

\author{
Davinia Palomares-Montero \\ M. ${ }^{a}$ José Chisvert-Tarazona \\ Universitat de València. Spain. \\ davinia.palomares@uv.es \\ maria.jose.chisvert@uv.es
}

\section{Cristóbal del Campo Ponz}

Centro de Formación, Innovación y Recursos del Profesorado (CEFIRE). Spain.

delcampoponz@hotmail.com

Received: 3/1/2021

Accepted: $15 / 4 / 2021$

Published: 23/9/2021

\begin{abstract}
Schools have a responsibility to prepare new generations born in a globalized and interconnected world. The main objective of this paper is to analyze the role that technology plays in the development of dialogical learning in learning communities. We try to understand the influence that technology has in fostering communication and interaction in an educational project that presents interaction and words as basic learning tools. An instrumental, interpretive, and embedded case study is applied in which the communicative methodology is developed from interviews and two discussion groups. The singular case involves a rural school constituted as a learning community that is geographically split into two villages; each village has its own lecture room, one with technology immersion (A) and another with progressive incorporation of technology (B). The results show the influence of the technological factor in learning development that facilitates the creation of meaning; a pedagogical principle that learning communities develop to promote dialogical learning.
\end{abstract}

Keywords: dialogical learning; learning communities; information and communication technologies; communicative methodology; learning and knowledge technologies

Resum. La tecnologia com a variable influent en el desenvolupament de l'aprenentatge dialògic

Les escoles tenen la responsabilitat de preparar les noves generacions que neixen en un món globalitzat i interconnectat. L'objectiu principal d'aquest treball és analitzar el paper de la tecnologia en el desenvolupament de l'aprenentatge dialògic en les comunitats d'aprenentatge. Intentem comprendre la influència que té la tecnologia per afavorir la comunicació i la interacció en un projecte educatiu que presenta la interacció i les paraules com a eines bàsiques d'aprenentatge. S'aplica un estudi de cas instrumental, interpretatiu i incrustat, sobre el qual es desenvolupa la metodologia comunicativa a partir d'entrevistes i dos grups de discussió. El cas singular és una escola rural, constituïda com una comunitat d'aprenentatge, que es divideix geogràficament en dos llogarets; cada poble té 
la seva pròpia sala de conferències, una amb immersió tecnològica $(A)$ i una altra amb incorporació progressiva de tecnologia $(\mathrm{B})$. Els resultats mostren la influència del factor tecnològic en el desenvolupament de l'aprenentatge en facilitar la creació de significat, principi pedagògic que desenvolupen les comunitats d'aprenentatge per promoure l'aprenentatge dialògic.

Paraules clau: aprenentatge dialògic; comunitats d'aprenentatge; tecnologies de la informació i la comunicació; metodologia comunicativa; tecnologies d'aprenentatge i coneixement

\title{
Resumen. La tecnología como variable influyente en el desarrollo del aprendizaje dialógico
}

Las escuelas tienen la responsabilidad de preparar a las nuevas generaciones en un mundo globalizado e interconectado. El objetivo principal de este trabajo es analizar el papel de la tecnología en el desarrollo del aprendizaje dialógico en comunidades de aprendizaje. Intentamos comprender la influencia que tiene la tecnología para favorecer la comunicación y la interacción en un proyecto educativo que presenta la interacción y las palabras como herramientas básicas de aprendizaje. Se aplica un estudio de caso instrumental, interpretativo e incrustado, sobre el cual se desarrolla la metodología comunicativa a partir de entrevistas y dos grupos de discusión. El caso singular es una escuela rural, constituida como una comunidad de aprendizaje, que se divide geográficamente en dos aldeas; cada pueblo tiene su propia sala de conferencias, una con inmersión tecnológica (A) y otra con incorporación progresiva de tecnología (B). Los resultados muestran la influencia del factor tecnológico en el desarrollo del aprendizaje al facilitar la creación de significado, principio pedagógico que desarrollan las comunidades de aprendizaje para promover el aprendizaje dialógico.

Palabras clave: aprendizaje dialógico; comunidades de aprendizaje; tecnologías de la información y la comunicación; metodología comunicativa; tecnologías de aprendizaje y conocimiento

\author{
Summary \\ 1. Introduction 4. Discussion \\ 2. Methods 5. Conclusion \\ 3. Results Bibliographical references
}

\section{Introduction}

Numerous studies have drawn attention to how student-centered methodologies can become the cornerstone of current pedagogy (Jang et al., 2016). This paper focuses on dialogical learning, which is characterized by seven principles (Flecha \& Puigvert, 1998): (1) egalitarian dialogue, which considers the contributions made by the subjects according to the validity of the arguments and not the position of power; (2) cultural intelligence, which starts from the capacities that individuals have to participate in an egalitarian dialogue; (3) transformation, given that dialogical learning transforms the relations between individuals and their environment; (4) instrumental dimension, because dia- 
logical learning also includes the necessary knowledge and skills; (5) creation of meaning, in which all individuals can dream, feel, and give meaning to their existence; (6) solidarity, given that egalitarian educational practices can only be based on concepts of solidarity; and (7) equality of differences, which is a fundamental value that should guide all progressive education.

We consider it necessary to analyze how the use of technology in education can provide a pedagogical response to facilitate such dialogical learning (Gros \& Suárez-Guerrero, 2016). The debate on whether technological devices are effective in education seems to have been overcome, giving way to considerations of how they are used on the basis of specific pedagogical models (Selwyn, 2013; Suárez-Guerrero et al., 2016). This is especially important during the COVID19 pandemic, as it has accelerated and increased the technological gap among citizens in technology access, use, and competence (Lai \& Widmar, 2020).

The digital nature of the new social context has led to the imperative need for a comprehensive rethinking of teaching. If the characteristics of the student body have changed, the educational institution is also changing. It could be proposed that there is a clash between traditional school culture (closed, univocal, traditional, and printed) and the new digital culture (liquid, popular, interactive, audiovisual, and hypertextual) (Blau \& Shamir-Inbal, 2017). The new digital culture supports the mediatization of knowledge, language, and communication in a very different way from teaching practices based on printed readings (Selwyn, 2013). ICT are the instruments and tools that can be used in relation to the treatment of information and communication. Thus, technology without pedagogy does not work (Suárez-Guerrero et al., 2016). In fact, the context in which technology is used has a greater influence on determining its effects than the specific technology used (Doyle, 2017; YudesGómez et al., 2018). In this sense, Hernann (2014, p. 5) affirmed that to achieve these processes of appropriation of technology in education, it is necessary to think about educational intentionalities, the decision of an educational and communicative model that proposes the meaningful use of tools in processes of knowledge transfer and learning.

If technology is part of the educational response and becomes one more variable of the educational reality, pedagogical questions must be raised to assess whether it is a complete alternative to educational needs (Gros \& Suárez-Guerrero, 2016). It is necessary to analyze how technology contributes to the teaching-learning process, as well as the assessment process, to understand the meaning and aim of technology in education, the meaning of the learning content, the social nature of learning, and the meaning, value, and mechanisms of the learning assessment.

Learning Communities (LC), to a large extent benefited by the dialogical learning they promote, take into account the way in which the information society builds relationships. LC constitute a dialogical process based on egalitarian participation. In this organizational environment, our hypothesis is that ICT make it possible to create new teaching and learning processes (DeCoito $\&$ Richardson, 2018) and assessment processes (Barberá, 2016) that could 
facilitate the opening of the school to better conditions of dialogical learning. The main goal of the research is to analyze how technology, understood as a structure of action and learning (Suárez-Guerrero, 2013), affects the development of dialogical learning as a methodological strategy in the context of an organizational project of the LC.

\section{Methods}

The study was approached from the communicative methodology that is positioned in the action theory model of Habermas (1987-2018) and Freire (1973). This methodological orientation recognizes contributions from phenomenological, constructivist, interactionist, or ethnomethodological positions, emphasizing the interactions that occur in social life, particularly those that promote social inclusion. It is a scientific option that considers social reality as a human construction where meanings are accessed in a communicative way through the interaction between individuals (Gómez, 2006). The communicative methodology proposes an "interpretative gap break" that displaces the researcher from the privileged place of analysis and establishes an egalitarian relationship with the researched individuals to propitiate dialogue (Gómez, 2006).

A qualitative research approach involving the application of a case study was used. The case was selected taking into consideration the possibility of having a "universal individualized" case (Yin, 2003) with the aim of understanding the facts that were produced for a later "analytical generalization" (Yacuzzi, 2005). For this reason, the selection of the case was: i) instrumental, as it was intentionally selected; ii) interpretative, because the goal was to extract meaning from the reality studied; and iii) embedded, because it centered on the analysis of some of the school's regulatory processes, in this case, the pedagogical process (Yin, 2003). The field survey was carried out during the 2014-2015 and 2015-2016 school years.

We analyzed the data obtained in the (1) interviews, which have enabled us to know the reality and to study the meaning-making process and (2) discussion groups, which have made it possible to confront the individual subjectivity with the group and jointly construct a common discourse (Gómez, 2006).

\subsection{Case description}

The case is a grouped rural school (GRS) constituted as an LC since 2003. The GRS is divided into two lecture rooms (referred to as A and B, respectively) in two similar localities close to each other in a rural environment. The two lecture rooms share the same management team and part of their teaching staff, the number of students is similar (42 students in class A and 38 students in class B during the 2013-2014 school year), as well as the types of groupings (by cycle: pre-primary, 1st-2nd grades, 3rd-4th grades, and 5th-6th grades). 
In lecture room A, self-sufficient classrooms were created a decade ago to make available to the students in the ordinary classroom all the resources that a computer room affords. In contrast, lecture room B did not implement this project, and technology was incorporated slowly. Therefore, the two lecture rooms differ in terms of their access to technology. Table 1 shows the distribution of the subjects participating in the research.

The information obtained in interviews and discussion groups was analyzed applying the content analysis method for its ability to extract in-depth knowledge of the values present in messages, texts, or speeches (PalomaresMontero et al., 2012). The whole study took into account four dimensions in the analysis (environmental, regulatory, epistemological, and practical) to understand what type of principles became significant to promote dialogical learning in the LC. In this paper, we present the results of the practical dimension aimed at knowing in depth the processes inherent to educational practice. We identify two categories in this dimension: the teaching-learning process, which analyzes how the educational process is structured; and the assessment process, which seeks information on how evaluation process of the educational practice is carried out.

Table 1. Research subjects

\begin{tabular}{|c|c|c|c|}
\hline Method & Agent & Lecture room $\mathrm{A}$ & Lecture room $\mathrm{B}$ \\
\hline \multirow{7}{*}{ Interview } & Veteran teachers & 4 & 2 \\
\hline & Novel teachers & 2 & 2 \\
\hline & Current students & 3 & 3 \\
\hline & Former students & 3 & - \\
\hline & Volunteer family & 2 & 1 \\
\hline & Non-volunteer family & 2 & 1 \\
\hline & Other agents & & \\
\hline \multirow{5}{*}{ Discussion groups } & Veteran teachers & 2 & 2 \\
\hline & Novel teachers & 2 & 2 \\
\hline & Volunteer family & 2 & 1 \\
\hline & Non-volunteer family & 2 & 1 \\
\hline & Other agents & \multicolumn{2}{|c|}{3} \\
\hline
\end{tabular}

Source: Own elaboration. 


\section{Results}

\subsection{Teaching and learning process}

The process of teaching and learning clearly responds to all principles that stimulate dialogical learning, particularly in lecture room A, which substantially benefits from the advanced use of ICT. The results for each are detailed as follows.

\subsubsection{Egalitarian dialogue}

In lecture room $\mathrm{A}$, dialogue benefits from questioning the position of power and privilege of the textbook in relation to the selection of curricular content. Learning is not generated from the contribution of knowledge mediated by a publisher that filters and interprets it; it disappears in benefit of the multiplication of references of diverse sources that are mostly technological, but also physical.

Complementarily, teachers assume that they are no longer the only source of knowledge and that students become active subjects of their learning process: "they know where they are going on the agenda, even if they do not carry a book because in the cloud, everything has its order, its meaning. They distinguish one relevant source from another that is not so relevant" (NOVEL TEACHER - lecture room A).

It is the validity of the arguments that modulates the suitability of the source. New profiles and networked learning experiences emerge. ICT mediate in this lecture room through technological devices, such as tablets and computers, access to the Internet and social networks, and the provision of software and apps, thus turning the selection and filtering of information into a pedagogical activity, into valuable and egalitarian procedural learning that questions power relations that have been naturalized until now in many schools.

Lecture room B has textbooks and is more reluctant to let go of the umbilical cord that ties it to the prescribed curriculum. The teachers value the benefit of this type of resource in facilitating the transition to secondary school, which also reproduces traditional pedagogical models:

In [lecture room $\mathrm{A}]$, the bad thing about using both the computer in primary is that in secondary, they didn't work like that, and they have to go back to using the pencil and the notebook. The use of the textbook avoids this problem. (VETERAN TEACHER - lecture room B)

The teaching staff assumes a relevant role in the choice of sources of knowledge, as well as in their interpretation, although the collaborative work that began in the 2015-2016 school year, coinciding with the second visit to the center in the field work, shows progress in the incorporation of the students as an active subject, as well as in the expansion of sources of knowledge used. 


\subsubsection{Cultural intelligence}

In lecture room A, the approach to popular culture, to the local from the ICT, enables participation in more innovative activities in which the students largely manage their own learning. The radio is a means of communication mediated by the technology that facilitates dialogical learning: the school reality is considered news, the context in which it takes root. The story, the texts, and the interviews are led by students of different ages. Although after the analysis of some of their productions (podcasts), the most relevant thing is the curricular meaning that their own lives take; the active role the students take as subjects that divulge knowledge. This learning is particularly valuable in a rural context.

ICT have transformed the students' learning environment in lecture room A by expanding it in terms of the number and variety of interactions with the context, which, at the same time, enables access to the globalized world. The blog, which has been available to lecture room A students since 2005, is a good example of the stimulation of cultural intelligence. Blogs open the doors to a virtual environment that relates what is done at school to what occurs in the population: "For example, the typical 'traveling book' that goes every weekend to a different house, with the blog going to all houses every weekend" (VETERAN TEACHER- lecture room A).

The nonexistence of a radio or blog in lecture room $B$, as evidenced during the interviews carried out in the first phase of the fieldwork, showed the difficulty of incorporating cultural intelligence to take root in the community from this lecture room. There is a lack of volunteers, of adults linked to the educational project who participate in carrying out the successful educational actions of an LC. As a result of the discussion groups, it has been possible to confirm that this situation reverts when a process of transformation begins in lecture room $\mathrm{B}$, and assumes the introduction of the technology and the consolidation of the LC similar to its own projects, through which the framework of meaning begins to be shared, thus favoring the appropriation of the technology. The radio or blog activities also began to be used in lecture room B.

\subsubsection{Transformation}

The preliminary results of the study showed that the transformation of relationships was particularly evident in lecture room B. The new teaching staff is normally assigned to this lecture room, making the incorporation of ITC as learning facilitators a challenging task. Organizational decisions are taken to facilitate stable teaching staff who are familiar with the LC project and the technological immersion process and to transfer their teaching to lecture room B. Families experience the proximity of school management, which makes a didactic effort mediated by technology aimed at promoting a better understanding of the projects developed by the school, thus enabling the generation of collaborative relationships: "shared virtual environments have created a collaborative working structure that has transformed the relationships between 
all educational agents of the GRS" (SCHOOL MANAGER). Therefore, school manager has been able to change the social functioning of the teams, clearly differentiated between lectures rooms A and B (senior and novel teachers, respectively).

The improvement in the teaching-learning processes is evident: volunteerism has increased, a culture of teacher collaboration between lecture rooms has been created, and the number and quality of successful actions programmed for the benefit of the learning teaching processes have increased. Given the significant physical distance between the two lecture rooms, these advances require the regular use of technological devices that enable dialogical communication.

In addition, the transformation transcends the GRS and its members. Lecture room A generates relevant synergies with the environment, constituting the seed of transformation of a dramatic socio-labor situation that threatened the future of the mining population. From this lecture room, situated in the village where the mine is located, a space of vindication and protest is generated. Some headlines in the center's online newspaper testify to the commitment of the school pupils to their environment, as well as to their transforming power through the exercise of egalitarian dialogue: "The school blog vindicated the mining struggle with the slogan 'We want coal to be burned and lighted, not for the Three Wise Men to bring it to us'" (VOLUNTEER FAMILY - lecture room A).

The struggle of the school and the demands of the entire population also obtain results. Two industrial projects were confirmed that began in 2020 in the region to facilitate the relocation of the mine employees. Moreover, the close communication with the high school, to which the students of the GRS are mainly referred, has led to an improvement in the high schools' teaching processes, as it is progressively incorporating technology and other activities of the LC by positively valuing the work carried out by the GRS to promote dialogical learning: "In some departments, they already work only with computers and interactive groups are already carried out in many subjects. These are elements that demonstrate networking and benefit the transition to secondary education" (VETERAN TEACHER - lecture room A).

\subsubsection{Instrumental dimension}

A curriculum that is lax in its level of exigency in instrumental subjects, such as mathematics or languages, could be considered appropriate in a GRS. However, in both lecture rooms, the instrumental dimension of learning is cared for. Nevertheless, the families and part of the teaching staff of lecture room A shared their complaints in the interviews. They explicitly criticized the use of tablets and other technological resources, as they felt that these tools did not fulfill the spelling requirement; an element that is evident in the transition to high school. After the communication of these results of our study, the management assumes this limitation and in the discussion groups proposes the introduction of a greater number of handwritten activities, an issue that is 
dealing with in the staff and incorporating: "Things that we have to improve ourselves: handwriting because of digital immersion, knowing how to do an exam because we work for projects" (SCHOOL MANAGER). In lecture room $\mathrm{B}$, this problem is not detected as the process of technological immersion remains incipient.

\subsubsection{Meaning creation}

The technology available in lecture room A provides versatile resources that enable new communicative opportunities and network participation. It benefits the diffusion of dialogical communicative activities that introduce the students' stories in the world through the newspaper, the blog, and the radio and improve the knowledge of other realities. "I believe that the methodology used is influenced by the use of ICT, as they open up a range of different possibilities to be connected with the world" (FORMER STUDENT - lecture room A). Their consideration as a global village gives meaning to a rural reality that needs to come out of its isolation.

Late access to these resources and their limited use in lecture room B shows how the creation of meaning can easily be stimulated with ICT. This is evident through the discussion groups, in which the teachers and the school management congratulate themselves on the significant progress that has been made in motivating the students of this lecture room with contextualized practices: "The reason for choosing the ICT immersion methodology is that the teachers believe that it is the best thing for children... . It makes sense because it connects the school to the population and the world" (SCHOOL MANAGER).

\subsubsection{Solidarity}

Discussion groups highlight the value of technology as a tool to improve professional development through coordination. This relationship of proximity, in which dialogical communication is established free from power relations, enables them to deepen the principle of solidarity. Lecture room B in particular, but not exclusively, has benefited from this situation, since the entry of the new management in the school:

The contact that we have between parallel teachers of each lecture room is very good, especially because I am novel. In addition to the weekly meeting we have in person, we communicate every day by email and even by Skype. (NOVEL TEACHER - lecture room B)

Successful actions require an attitude of solidarity on the part of the participating volunteers, as well as on the part of the students, who rely on learning, particularly in interactive groups:

From 5th grade, we help 3rd grade mates to learn how to use the computer, how to organize things on the Internet and search engines and all that. When you go to 3rd grade, you are a little lost and need help. (CURRENT STUDENT - lecture room A) 
Moreover, as one teacher stated, "The radio has been an incentive for the older students. They are eager to prepare the program, to set it up, to help each other" (VETERAN TEACHER - lecture room B). In these groups, a rare practice is observed: the technology also brings teachers together through Skype in lecture room A: "At noon, we connected and agreed on the details of some activities [...] we commented on Skype" (VETERAN TEACHER lecture room A). Although collaborative work by itself does not produce learning outcomes, it is key that groups engage in productive interactions (Dillenbourg et al., 2009).

\subsubsection{Equality of differences}

The lecture rooms in both populations are characterized by a diversity of race, age, and gender. In lecture room A, technology enables individualized attention and monitoring of the students' work to better adapt it to their specific needs. Dialogical learning in pursuit of this principle occurs in every communicative interaction born of respect: students of different ages, races, and genders working in teams.

The families of the students in lecture room A recognize that the school has bridged the gap between immigrants and the local community inside and outside the school:

There are even English classes for parents, Spanish classes for immigrant mothers... well, English classes are given by the English teacher, Spanish classes are given by two mothers who help two other Moroccan mothers and have made good progress... . We have also helped each other to learn how to use the mail and to be able to consult the blog. (VOLUNTEER FAMILY - lecture room A)

Technology mediates the achievement of this learning by multiplying interactions and reducing isolation. A better knowledge of the world makes it easier to understand the richness of diversity. This inclusive treatment occurred to a lesser extent in lecture room B, where the distance between native and foreign families was palpable: "The first immigrant population that came was Romanian, very similar to us, but closed groups were made. And that in a small town is increasingly marked" (VOLUNTEER FAMILY - lecture room B).

\subsection{Assessment process}

The evaluation process introduces some of the principles of dialogical learning. The egalitarian dialogue and instrumental dimension are highlighted in the assessment.

\subsubsection{Egalitarian dialogue}

The self-regulatory process of student learning is evident in the autonomous control over assessment processes, amplified by dialogical communication, of special interest in peer evaluation. Lecture room A teachers shed their author- 
ity figure in some assessment processes, in which this role is extended to the students, particularly in technology-mediated activities. Students aged 10-12 in lecture room $\mathrm{A}$ are able to assess whether a radio program had flaws in the editing, whether the texts read were not cohesive or whether the slides on the blog were not in order. All productions made during the teaching-learning process are evaluated as a portfolio, so the students are aware of their continuous assessment. Lecture room A carries out certain activities that are considered global and more significant, such as radio, exhibitions, or digital creations, which incorporate self-evaluation and heteroevaluation processes and improve the student learning process. In this regard, one family stated that "You realize that children learn to solve each other's problems; it seems as if they don't need us" (VOLUNTEER FAMILY - lecture room A).

In lecture room $\mathrm{B}$, where an incipient use of technology was observed at the beginning of the fieldwork, the teaching staff was solely responsible for the assessment. Advances in access to technology have enabled them to bring their practices closer to those of lecture room A, but final exams make self-regulation processes and egalitarian dialogue difficult:

The attitude, the way of organizing oneself, the ability to look for information, to find solutions in a different way, teamwork ... all of this we take into account, although it is true that the exams are the most important thing in the grade. (NOVEL TEACHER - lecture room B)

\subsubsection{Instrumental dimension}

The assessment of the instrumental dimension benefits from the provision of technological artifacts, mathematics or language programs, and activities that enable self-correction. With a greater introduction of technology, which is more typical of lecture room A, these evaluative practices are more common. The autonomy it creates benefits individualized progress, which is particularly relevant in clustered schools. While these technical and mechanical corrections do not explicitly connect with dialogical learning, they do allow for times that can be allocated to reflective and self-regulatory evaluation:

Learning becomes more instantaneous because feedback is not delayed; students see their mistakes earlier and do not have to depend on the teacher and even on explanations. In addition, the amount of resources that are in the network helps a lot so that each child can progress according to his rhythm. (NOVEL TEACHER - lecture room A)

In the first phase of the fieldwork, the teaching staff of lecture room B was observed to largely depend on correction processes, which slowed down the students' progress, particularly when such practices are not shared by all students in the classroom. This reality is modified with the progressive introduction of ICT, with self-correction processes common in the second phase of fieldwork. Both students and teachers value it as very beneficial: "When they [lecture room B] listen to each other, they realize whether they are doing well 
or not, what they have to improve. They are working hard because they realize what they are doing well or badly (self-regulation, feedback)" (SCHOOL MANAGER).

\section{Discussion}

The results show that the ICT variable influences the improvement of dialogical learning carried out in the LC. The current debate on how technological devices are used on the basis of which pedagogical models (Selwyn 2013; Suárez-Guerrero et al., 2016) has led us to conclude, in line with Selwyn (2013), that the new digital supports mediatize knowledge, language, and communication in a very different way from teaching practices based on printed readings and centered on teachers. It has been confirmed that technology is at the service of teaching and learning processes. This is the only way to give them meaning in a school (Suárez-Guerrero et al., 2016) and responds to the LC educational project by favoring the improvement of dialogical learning in each of the principles it promotes.

As the results confirm, the LC has been consolidated as a project due to the pedagogical use of ICT that have been transformed into learning and knowledge technologies in lecture room A (in process in lecture room B), showing the benefits indicated by Correa et al. (2012) and López et al. (2011). The ecosystemic nature of the space/time of learning mediated by ICT has provided this rural school an opportunity to overcome isolation, enabling the empowerment and participation of students in line with Hernann (2014) in the classroom characterized by technological immersion.

Benefits have also been noted in the evaluation processes by mediating technology in line with Barberás (2016) contributions and following the principles of dialogical learning (Flecha \& Puigvert, 1998).

This finding is even more notable if we assess the bidirectionality of the relationship between both projects (the technological one and the LC) because the community is the vehicle through which technology can make sense of use. Thus, it is a reciprocal relationship of mutual benefit: the LC is consolidated as a result of technology and, at the same time, the LC has enabled a transformation in the use of technology from ICT to learning and knowledge technologies.

Moreover, ICT favor the integral formation of students to encourage their active participation in society. The shift from teaching to participation implies accepting new training opportunities that involve working with another notion of learning (Suárez-Guerrero, 2013), which is proposed and explained in this paper: dialogical learning. The pedagogical processes developed in the LC have been positively influenced by ICT to develop the virtual dimension that the subject must have to understand and participate in today's digital society. In fact, differences have been observed between the lecture rooms according to how ICT were used in the teaching-learning process. At present, in both lecture rooms, technology is an instrument that favors interaction with 
the environment and the individuals who inhabit it and provides a quantitative and qualitative increase in interactions and access to knowledge. ICT provide students with a greater degree of freedom and the possibility of experimentation, which are a social condition for learning.

\section{Conclusion}

We can conclude that the use of ICT in the LC under study has placed all members of the educational community on an equal footing, recognizing the value of cultural intelligence and benefiting the establishment of egalitarian relations.

At the same time, the teaching profile has influenced the way in which technology is used. The teachers in Lecture room A are identified as having an innovative profile, where technology is integrated through an immersion methodology. What is substantially transformative is that the staff who master this methodology of technological immersion create spaces of collaboration with the rest of the teachers to ensure that this advanced use of technology in the classrooms becomes widespread (Rodríguez \& Pozuelos, 2009). Therefore, it can be concluded that technology is enabling the development of the principle of solidarity in the LC and, as Oxfam Intermón suggests, it is possible to establish networks of help and collaboration from the computer, that is, a digital solidarity can be developed through technology.

Additionally, we have evaluated how the use of ICT has favored the participation and opening of the population. Among other factors, the principle of opening up to the outside world and transforming the environment has been promoted as a result of the use of ICT in schools, which is an element of transformation. Interviews and discussion groups allow us to conclude that the influence of the incorporation of ICT in homes, shops, and associations has contributed to the consolidation of the LC. The establishment of dialogical learning relations between individuals is reinforced by creating situations and learning spaces around ICT based on practical knowledge, generated from the use and experience with technology, thus enabling the promotion of the principle of egalitarian dialogue in all members of the community. With respect to the limitations, it should be noted that the study did not have an advisory council. The communicative methodology applied in this work proposes the participation of such an agent in the research as an organizational entity that provides knowledge and guidance on the development of the project (Gómez, 2006).

Finally, future research could focus on the comparison of the ICT factor in an LC with other school models. In these centers, ICT should be used at an advanced level to analyze the influence of ICT on the type of organizational and pedagogical project proposed in each center. These lines of research would contribute to the academic discussion around LC as a model of social transformation and ICT as a tool to facilitate this transformation. 


\section{Bibliographical references}

BArberÁ, E. (2016). Technological contributions to e-assessment. Revista de Educación a Distancia, 50. <http://dx.doi.org/10.6018/red/50/4>

Blau, I., \& Shamir-Inbal, T. (2017). Digital competences and long-term ICT integration in school culture: The perspective of elementary school leaders. Education and Information Technologies, 22, 769-787. <https://doi.org/10.1007/s10639-015-9456-7>

Correa, A., Escarbajal, A., \& IzQuierdo, T. (2012). La formación del profesorado desde una perspectiva interdisciplinar [Teacher training from an interdisciplinary perspective]. REIFOP, 14(1), 27-42.

DeCoito, I., \& Richardson, T. (2018). Teachers and technology: Present practice and future directions. Contemporary Issues in Technology and Teacher Education, $18(2), 362-378$.

Dillenbourg, P., Järvela, S., \& Fischer, F. (2009). The evolution of research on computer-supported collaborative learning. In N. BAlachefF, S. Ludvigsen, T. De Jong, A. Lazonder, \& S. Barnes (Eds.). Technology-enhanced learning: Principles and products (pp. 3-20). Cham: Springer.

Doyle, T. (2017). Weapons of math destruction: How big data increases inequality and threatens democracy by Cathy O'Neil. The Information Society, 33(5), 301-302. <https://doi.org/10.1080/01972243.2017.1354593>

Flecha, R., \& Puigvert, L. (1998). Aportaciones de Paulo Freire a la educación y las ciencias sociales [Paulo Freire's contributions to education and social sciences]. REIFOP, 33(12), 21-28.

Freire, P. (1973). La educación como práctica de libertad [Education as a practice of freedom]. Montevideo: Tierra Nueva.

Gómez, A. (2006). Metodología comunicativa-critica [Communicative-critical methodology]. Barcelona: Roure.

Gros, B., \& SuÁrez-Guerrero, C. (Eds.) (2016). Pedagogía red. Una educación para tiempos de internet [Network pedagogy: Education for the Internet era]. Octahedron/ICE-UB.

Habermas, J. (2018). Teoría de la acción comunicativa (M. Jiménez Redondo, Trans.). Madrid: Trotta Editorial. (Original work published ca. 1987).

Hernann, A. (2014). El uso de ordenadores y tecnologías digitales en los procesos de aprendizaje en la era digital [The use of computers and digital technologies in the learning process in the digital era]. Congreso Iberoamericano de Ciencia, Tecnología, Innovación y Educación. 12-14 November, Buenos Aires, Centro Singular e-learning.

Jang, H., Kim, E. J., \& Reeve, J. (2016). Why students become more engaged or more disengaged during the semester: A self-determination theory dual-process model. Learning and Instruction, 43, 27-38. $<$ https://doi.org/10.1016/j.learninstruc.2016.01.002>

LaI, J., \& Widmar, N. O. (2020). Revisiting the digital divide in the COVID-19 era. Applied Economic Perspectives and Policy, 43(1), 458-464. $<$ https://doi.org/10.1002/aepp.13104>

López, M., Sánchez, M., \& Altopiedi, J. (2011). Comunidades profesionales de práctica que logran sostener procesos de mejora institucional en las escuelas [Professional communities of practice that succeed in sustaining institutional improvement processes in schools]. Revista de Educación, 356, 109-131. 
Palomares-Montero, D., García-Aracil, A., \& Castro-Martínez, E. (2012). Misiones actuales de las universidades públicas: Una perspectiva sociológica [Current missions of public universities: A sociological perspective]. ARBOR, 188(753), 171-192. $<$ https://doi.org/10.3989/arbor.2012.753n1011>

Rodríguez, F. P., \& Pozuelos, F. J. (2009). Aportaciones sobre el desarrollo de la formación del profesorado en centros TIC. Estudio de caso [Contributions on the development of teacher training in ICT centers: Case study]. Pixel-Bit, Revista de Medios y Educación, 35, 33-43.

SELWYN, N. (2013). Rethinking education in the digital age. In K. OrTON-Johnson \& N. Prior (Eds.). Digital sociology: Critical perspectives (pp. 197-212). Basingstoke: Palgrave Macmillan.

Suárez-Guerrero, C. (2013). Comunidad y alfabetización múltiple como condiciones de aprendizaje en red [Community and multiple literacies as conditions for networked learning]. In M. J. Chivert-Tarazona, A. Ros-Garrido \& V. HorCas López (Coords.). A propósito de la inclusión educativa. Una mirada ampliada de lo escolar (pp. 250-271). Barcelona: Octaedro.

Suárez-Guerrero, C., Lloret-Catalá, C., \& Mengual-Andrés, S. (2016). Teachers' perceptions of the digital transformation of the classroom through the use of tablets: A study in Spain. Comunicar, 49(XXIV), 81-89.

<https://doi.org/10.3916/C49-2016-08>

YACUZZI, E. (2005). El estudio de caso como metodología de investigación: teoría, mecanismos causales, validación [The case study as a research methodology: Theory, causal mechanisms, validation]. Universidad del CEMA. Working Paper, no. 296.

YIN, A. (2003). Applications of case study research. London: SAGE Publications.

Yudes-Gómez, C., Baridon-Chauvie, D., \& González-Cabrera, J. M. (2018). Cyberbylling and problematic Internet use in Colombia, Uruguay and Spain: Cross-cultural study. Comunicar, 56(XXVI), 49-58.

<https://doi.org/10.3916/C56-2018-05> 